NIHON REOROJĪ GAKKAISHI Vol. 22, No. 2, 129 134 (1994)

(C)1994 The Society of Rheology, Japan

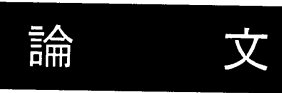

Viscoelasticity and Birefringence of Poly(2-vinylnaphthalene)

E. J. Hwang*1, Tadashi InOuE*1, Kunihiro Osaki*1, and Atsushi TAKAnO*2

${ }^{* 1}$ Institute for Chemical Research, Kyoto University, Uji, Kyoto 611

*2Nagaoka Technological University, Kamitomioka, Nagaoka, Niigata 940-21

Complex Young's modulus, $E^{*}(\omega)$, and complex strain-optical coefficient, $O^{*}(\omega)$, of Poly (2-vinylnaphthalene) (P2VN) were studied in the glass-to-rubber transition zone at frequencies ranging from 1 to $130 \mathrm{~Hz}$ at various temperatures between $145^{\circ} \mathrm{C}$ and $200^{\circ} \mathrm{C}$. In comparing the master curves of $E^{*}(\omega)$ and $O^{*}(\omega)$, we apply the modified stress-optical rule to deliberate the glass transition modulus attributable to different relaxation mechanisms. The characteristics of master curves are also compared with those of polystyrene (PS), poly ( $\alpha$-methylstyrene) (PMS), and polycarbonate $(\mathrm{PC})$ in view of their chemical structures. The stress-optical coefficient, $C_{\mathrm{R}}$, determined in the rubbery zone, is $-8.3 \times 10^{-9} \mathrm{~Pa}^{-1}$, which is 1.6 times larger than that of PS. The large negative value may be due to the large optical anisotropy of naphthyl side group. In the glassy zone, the relative rate of decrease of $E^{\prime \prime}(\omega)$ with $\omega$ is lower compared with the other polymers. This behavior is believed to be attributed to $\beta$ relaxation of large naphthyl side group. Compared with the strain-optical coefficients of three other polymers, the $O^{\prime \prime}(\omega)$ of P2VN is found to be inactive to the $\beta$ relaxation.

Key words : Birefringence/Young's modulus/Stress-optical rule/

Poly (2-vinylnaphthalene) $/ \beta$ relaxation

\title{
ポリ( 2-ビニルナフタレン)の粘弾性と複屈折
}

\author{
黄 義正 ${ }^{* 1} \cdot$ 井上 正志*1 $・$ 尾崎 邦宏*1 ・ 高野 敦志*2
}

（原稿受理：1993年12月3日）

\section{1. 緒 論}

無定形高分子のガラス状からゴム状への転移領域の粘弾性は, 狭い温度範囲で力学的特性が急激に変化する興味深い領域であ る.この領域には，ゴム状とガラス状にそれぞれ関連のある緩和 機構が複合的に寄与していると思われるが11), 2), 二つの機構の分 離測定は確立されていない，高分子の溶液および溶融体に対する 複屈折の測定は, 粘弾性の研究之相補的に広く行われており, 応 力の発生機構におけるセグメントの概念の確立に大きく寄与し $た^{3), 4)}$. 我々は複屈折測定を無定形高分子のガラス転移領域へ拡 大し, 特性基を系統的に変えた多種の高分子に対し, 動的複屈折 と動的粘弾性を同時に測定することによって, 分子鎖構造と応力 および複屈折の発生機構との関係を解釈して有用な結果を得てき

*1京都大学化学研究所 $\overline{\mathbf{T}} 661$ 京都府宇治市五ヶ庄

*2長岡技術科学大学化学系 $=940-21$ 新潟県長岡市神富岡
た5) 9). 今までに研究した高分子は側鎖としてフェニル基または それより小さい基(例えばメチルなど)を含むものであった．側鎖 の光学的異方性が異なる高分子の複屈折挙動を, 今までに調べた 高分子の挙動之比較するのは興味深い. 本研究では, 光学的異方 性が特に大きいナフチル基を含むポリ（2-ビニルナフタレン) (P2 $\mathrm{VN})$ の粘弾性と複屈折を測定し, 今までの研究と比較すること を目的とする.

\section{2. 動的複屈折および修正応力 - 光学則}

$2 \cdot 1$ 複素ヤング率 $\boldsymbol{E}^{*}(\omega)$ と複素ひずみ - 光学係数 $\boldsymbol{O}^{*}(\omega)$ 無定形高分子に, 時間により周期的に変形する単軸ひずみ, $\varepsilon(t)=\varepsilon_{0} \sin \omega t$

を加えると, 周波数 $\omega$ は同じであるが位相 $\delta$ だけ進んだ応力, $\sigma(t)=\sigma_{0} \sin (\omega t+\delta)$

が生じる. また, 延伸方向の屈折率 $n_{11}$ と延伸方向に垂直な方向 の屈折率 $n_{22}$ との差である複屈折 $\Delta n$ は, 


$$
\Delta n(t)=n_{11}-n_{22}=\Delta n_{0} \sin \left(\omega t+\delta_{\mathrm{B}}\right)
$$
で表される.この時, 位相差 $\delta, \delta_{\mathrm{B}}$ は一般的に同一でない. 複素弾 性率 $E^{\prime}(\omega), E^{\prime \prime}(\omega)$ は

$$
E^{\prime}(\omega)=\left(\delta_{0} / \varepsilon_{0}\right) \cos \delta, E^{\prime \prime}(\omega)=\left(\delta_{0} / \varepsilon_{0}\right) \sin \delta
$$

で定義され, 複素弾性率に対応する複素ひずみ - 光学係数 $O^{*}(\omega)\left[=O^{\prime}(\omega)+i O^{\prime \prime}(\omega)\right]$ は次の式で定義される.

$$
O^{\prime}(\omega)=\left(\Delta n_{0} / \varepsilon_{0}\right) \cos \delta_{\mathrm{B}}, O^{\prime \prime}(\omega)=\left(\Delta n_{0} / \varepsilon_{0}\right) \sin \delta_{\mathrm{B}}(5)
$$

\section{$2 \cdot 2$ 応力 - 光学則之修正応力 - 光学則}

無定形高分子のゴム平坦領域および流動領域で応力緩和を测定 する時, 弾性率と光学係数の間では次のような関係が成り立つ. これは応力 - 光学則 (stress-optical rule) と呼ばれる関係の例で ある4).

$$
O(t)=C_{\mathrm{R}} E(t)
$$

動的測定では応力 - 光学則は次の式で表される.

$$
O^{\prime}(\omega)=C_{\mathrm{R}} E^{\prime}(\omega), O^{\prime \prime}(\omega)=C_{\mathrm{R}} E^{\prime \prime}(\omega)
$$

ここで $C_{\mathrm{R}}$ は応力 - 光学係数で, 周波数および温度に依存しない 一定な值と仮定される. 式(7)の成立は多くの無定形高分子におい て確認された5) 9). しかし，ガラス転移領域およびガラス状領域 では, 複屈折の符号が反転する高分子が多く，上記の光学則は成 り立たなくなる.

我々は, ガラス状領域の弾性率とひずみ - 光学係数の比較か ら, $O^{\prime \prime}(\omega)$ と $E^{\prime \prime}(\omega)$ との比例関係を見い出した5).

$$
O^{\prime \prime}(\omega)=C_{\mathrm{G}} E^{\prime \prime}(\omega)
$$

ここで $C_{\mathrm{G}}$ は周波数および温度に依存しない一定な值である.こ の関係を応力 - 光学則と結合し，流動領域からガラス領域にわた る複屈折の新しい解釈方法として, 次のような修正応力 - 光学則 (modified stress-optical rule) を提案した ${ }^{5}$.

$$
\begin{aligned}
& E^{*}(\omega)=E_{\mathrm{R}}^{*}(\omega)+E_{\mathrm{G}}^{*}(\omega), \\
& O^{*}(\omega)=C_{\mathrm{R}} E_{\mathrm{R}}^{*}(\omega)+C_{\mathrm{G}} E_{\mathrm{G}}^{*}(\omega)
\end{aligned}
$$

添字 $\mathrm{R}, \mathrm{G}$ はそれぞれゴム状とガラス状領域を意味する.

\section{3. 実験}

ポリ（2-ビニルナフタレン）(P2VN) はラジカル重合により得 た. GPC によるスチレン換算分子量は $3.0 \times 10^{5}$ であった． P 2 VN の $3.4 \%$ ンゼン溶液から，溶媒蒸発法により $500 \mu \mathrm{m}$ 厚さの膜を 作成した．膜は測定の前， 24 時間真空乾燥した。

測定装置は，動的延伸レオメター（Rheospectoler, Rheology Co., Ltd., Kyoto, Japan）に複屈折測定装置を取り付けて，動的 弾性率と動的複屈折が同時に測定できるように組み合わせて使用 した．複屈折測定装置は, He-Neレーザー, 二つの偏光板, 補正 板，光測定装置を組み合わせたものである．装置の詳細は既に報

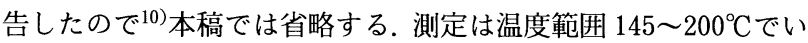
くつかの温度を選び, 各温度で周波数 $1 \sim 130 \mathrm{~Hz}$ の範囲に渡って 測定を行った。

\section{4. 結果および考察}

\section{$4 \cdot 1$ 動的ヤング率 $E^{*}(\omega)$ とひずみ - 光学係数 $O^{*}(\omega)$ の合成 曲線}

種々の温度で測定した動的弾性率とひずみ - 光学係数を総括的 に考察するため，時間 - 温度換算則を適用することによって合成 曲線を作成した． $E^{*}(\omega)$ と $O^{*}(\omega)$ の合成曲線を Fig. 1 に示す.
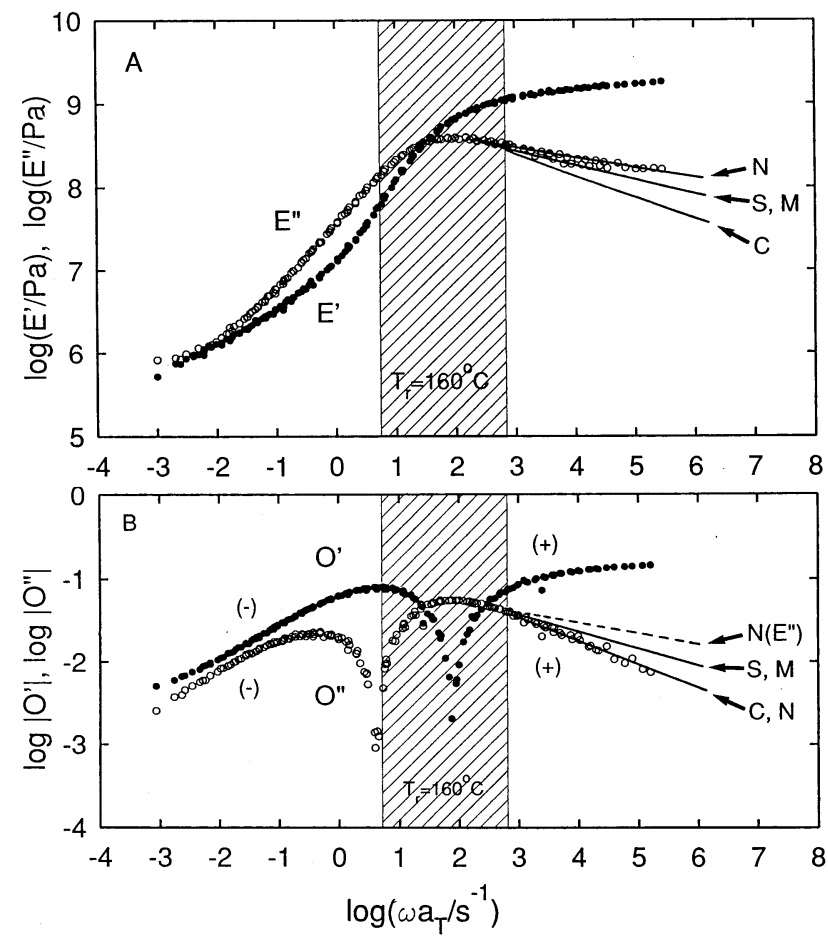

Fig. 1 Master plots of temperature-reduced A) complex Young's modulus, and B) complex strain-optical coefficient of P2VN. The reference temperature is $160^{\circ} \mathrm{C}$. The $\mathrm{N}, \mathrm{S}, \mathrm{M}$, and $\mathrm{C}$ in figures represent $\mathrm{P} 2$ VN, PS, PMS, and PC, respectively. Thick lines characterize their respective properties of $E^{*}(\omega)$ or $O^{*}(\omega)$, and dotted line in B) corresponds to $E^{\prime \prime}$ $(\omega)$ of P2VN.

合成曲線は, 各温度で測定したデー夕の両対数グラフを, 周波数 軸の水平移動によって重ね合わせて合成曲線を作った. 温度の変 化による密度変化の補正は行わなかった，ガラス転移領域では, 二つの相異なる緩和挙動が複合的に重なって表されるという多数 の報告があり ${ }^{1), 2)}$ ，この領域での時間 - 温度換算則の適用に関し ては多くの議論がある ${ }^{11)}$. 厳密にいうと, Fig. 1 の重ね合わせに むこの問題があるが, 以下の定性的な比較には差し支えない, 温 度依存性については 4.6 項で詳述する. 図中の直線と点線につい ては 4.2 項で述べる.

Fig. 1 の斜線領域は基準温度 $T_{\mathrm{r}}=160^{\circ} \mathrm{C}$ で測定した周波数域を 表す. 基準温度 $T_{\mathrm{r}}$ は, 周波数 $10 \mathrm{~Hz}$ で $E^{\prime \prime}(\omega)$ が $10^{8} \mathrm{~Pa}$ になる温 度を選んだ．異なる分子構造を持つ様々な無定形高分子の特性比 較の基準として, 既に報告した文献でもこの基準に基づいて合成 曲線を作成した ${ }^{5) \sim 9)}$. 高周波数領域の $E^{\prime \prime}$ デー夕の若干の不一致 を除いては, $E^{*}(\omega), O^{*}(\omega)$ 合成曲線はうまく作成されたのがわ かる. P2VN の $E^{*}(\omega)$ は $10^{9} \mathrm{~Pa}$ から $10^{6} \mathrm{~Pa}$ まで急激に变化し, 典型的な無定形高分子の挙動である.さらに低周波数側のゴム状 領域は測定不可能であったが, 測定結果から推定して低いゴム平 坦弾性率, $E_{\mathrm{N}}{ }^{\prime}\left(<10^{5.5} \mathrm{~Pa}\right)$ を持つ傾向を見せる. $E_{\mathrm{N}}{ }^{\prime}$ はゴム弾性 理論 ${ }^{12)}$ から

$$
E_{\mathrm{N}}{ }^{\prime}=3 \rho R T / M_{\mathrm{e}}
$$

で表される。ここで $M_{\mathrm{e}}$ はからみ合い分子量である。(10)式によれ 


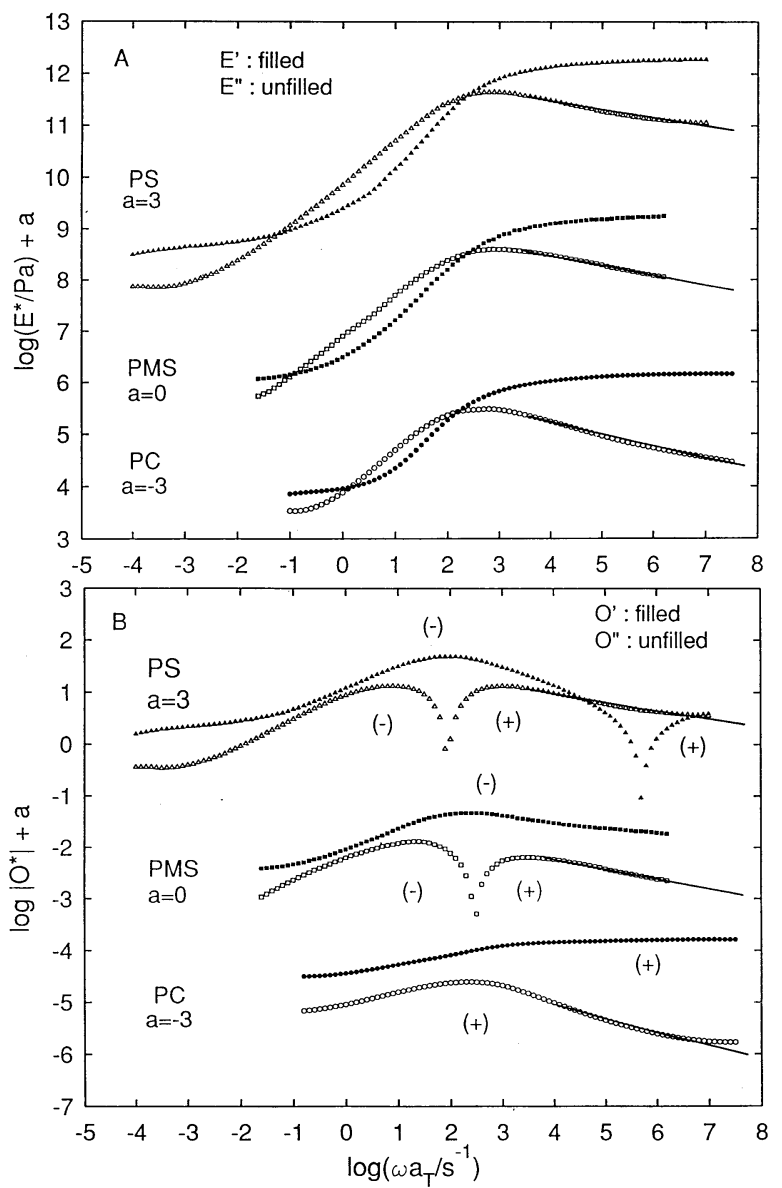

Fig. 2 Comparison of the master plots of A) $E^{*}(\omega)$, and B) $O^{*}(\omega)$ for PS, PMS, and PC. Lines on data characterize their frequency dependence of $E^{\prime \prime}(\omega)$.

ば P2VN は相当大きい $M_{\mathrm{e}}$ を持っていると考えられる.

同時に測定したひずみ - 光学係数 $O^{*}(\omega)$ の変化では複雑な周 波数依存性が見られる. 周波数が増加するにしたがって, $O^{\prime}(\omega)$ と $O^{\prime \prime}(\omega)$ は負 $\left(n_{11}-n_{22}<0\right)$ から正へ変化する. 符号の変化する 周波数は， $O^{\prime}(\omega)$ に比べて $O^{\prime \prime}(\omega)$ の方が 1 桁程度低い. この結果 はポリスチレン(PS) と定性的に一致する ${ }^{5)}$. PS に比べて正の領 域が相対的に低周波数側に寄っており, これは $O^{\prime}(\omega), O^{\prime \prime}(\omega)$ が 0 になる点での $E^{\prime \prime}(\omega)$ の挙動をPS と比較するとよくわかる (Fig. 2(B) 参照).

\section{$4 \cdot 2$ 他の高分子の $E^{*}(\omega)$ と $O^{*}(\omega)$ との比較}

$\mathrm{P} 2 \mathrm{VN}$ と他の高分子との特性を比較するため, すでに報告した $\mathrm{PS}^{5)}$, ポリ ( $\alpha$-メチルスチレン) (PMS) $)^{6)}$, ポリカーボネート $(\mathrm{PC})^{7)}$ の $E^{*}(\omega)$ と $O^{*}(\omega)$ を Fig. 2 に表す. Fig. 3 に 2 VN と 三つの高分子の分子構造を示す. 今までに測定された高分子で は, $O^{*}(\omega)$ の定性的な挙動はこれら三つの高分子のいずれかと 同じである.この領域での $E^{*}(\omega)$ は高分子の種類に関係なくほ とんぞ同じ緩和挙動を見せ, $E^{*}(\omega)$ のスペクトルからは高分子の 化学構造と関係した情報を得るのが非常に難しい. それに比べ, 複屈折の周波数依存性は高分子の構造によって異なる挙動を示 し, ガラス転移領域での緩和の詳細な情報を得ることができると 期待される.<smiles>CC(C)(C)c1ccc2ccccc2c1</smiles>

P2VN<smiles>CC(C)(C)CC(c1ccccc1)C(C)(C)C</smiles>

PS<smiles>CC(C)(C)CCC(C)(CC(C)(C)C)c1ccccc1</smiles><smiles>CC(C)(C)Oc1ccc(C(C)(C)c2ccc(OC(=O)C(C)(C)C)cc2)cc1</smiles>

BPA-PC

Fig. 3 The molecular structures of repeating unit for P2VN, PS, PMS, and PC.

Fig. 2 (A) の三つの高分子の $E^{*}(\omega)$ は, 無定形高分子のガラ 又転移近傍での特徴的な挙動を示し，互いによく似ている．定量 的な違いは低周波数域のゴム平坦弾性率 $E_{\mathrm{N}}{ }^{\prime}$ の高さで, 上述した ように $M_{\mathrm{e}}$ の差異に起因する. あう一つの定量的な違いは, 高周 波数域での $E^{\prime \prime}(\omega)$ の周波数依存性である. Fig. $2(\mathrm{~A})$ で各高分子 の $E^{\prime \prime}(\omega)$ にあわせて引いた直線を，比較のために Fig. 1（A）の 高周波数域へ書き写した. 図の中の $\mathrm{S}, \mathrm{M}, \mathrm{C}, \mathrm{N}$ は PS, PMS, $\mathrm{PC}, \mathrm{P} 2 \mathrm{VN}$ を表す. 周波数の増加に伴う $E^{\prime \prime}(\omega)$ の減少率は PC が 最む大きく, P2VN が最も小さい. PS と PMS は同じで, PC と P $2 \mathrm{VN}$ の間に位置する $(\mathrm{PC}>\mathrm{PS}=\mathrm{PMS}>\mathrm{P} 2 \mathrm{VN}) . E^{\prime \prime}(\omega)$ は近似的 な応力緩和スペクトルであるから, $E^{\prime \prime}(\omega)$ の差異は, 各高分子の 緩和スペクトルの違いを表している.この領域は $\alpha$ 緩和の短時間 側領域であり，今まで測定した phenyl 基が主鎖に含まれている 高分子の場合, この領域での $E^{\prime \prime}(\omega)$ の周波数による变化（例えば 減少率）はPC と同程度であった. P2VN, PS, PMS では減少率 が比較的小さく, 周波数が高くなるにつれて, 直線 C からの外れ が著しくなる.この外れは $\alpha$ 緩和の短時間側のガラス状領域に存 在する副緩和によるものと推定される. Fig. 3 の高分子の側鎖構 造を見ると, P2VN は最む大きい naphthyl 基を, PS, PMS は phenyl 基を, PC は小さい methyl 基を持つ. この側鎖の大きさ の順序は $E^{\prime \prime}(\omega)$ の減少率の低さの順序と一致している.

一方, Fig. 2(B) の $O^{*}(\omega)$ を見ると, $E^{*}(\omega)$ とは違って高分子 によって著しく異なった挙動を示す. P2VN はPS と似ていて, $O^{\prime}(\omega)$ 屯 $O^{\prime \prime}(\omega)$ 屯符号が変化する. P $2 \mathrm{VN}$ とS の $O^{\prime \prime}(\omega)$ は符号 の变化する前後で正と負の二つの極大を示し, P2VN のガラス状 領域側の正の極大が特に大きくなっている. また P $2 \mathrm{VN} の$ $O^{\prime}(\omega)$ はS より低周波数領域で符号が変化している. PS の $\alpha$ 位置に methyl 基が導入されている PMS の $O^{\prime}(\omega)$ は全領域に 渡って負を示す. phenyl 基が主鎖へ含まれている PC は全領域 で正を示す.

このような動的複屈折の挙動の中で, ガラス領域での $O^{\prime \prime}(\omega)$ に 特に着目しょう. Fig. 2(B) の直線で示した各高分子のガラス領 域での $O^{\prime \prime}(\omega)$ は, Fig. 2(A) の $E^{\prime \prime}(\omega)$ と式(8)の比例関係があり, 修正応力-光学則の基礎になる. Fig. 1(B)の高周波数域へ Fig. 2(B) のそれぞれの $O^{\prime \prime}(\omega)$ 直線を書き写す. Fig. 1(A)の $E^{\prime \prime}(\omega)$ の直線部分と重ね比べると, PS, PMS, PC に対しては式(8)の関 係が見付けられる。しかし，P2VN はこの関係が成り立たない。 Fig. 1(B) の波線は $\mathrm{P} 2 \mathrm{VN}$ の $E^{\prime \prime}(\omega)$ を表す。実線 $\mathrm{N}$ の $O^{\prime \prime}(\omega)$ と 
波線 $\mathrm{N}\left(E^{\prime \prime}\right)$ の $E^{\prime \prime}(\omega)$ との傾きが大きく異なるのがわかる．これ については， $E^{\prime \prime}(\omega)$ には側鎖による副緩和の寄与が明らかである が， $O^{\prime \prime}(\omega)$ には寄与が少ないと考えれば理解することができる. これは今回初めて観測された挙動である.この領域での P2VN の $\omega$ の増加に伴う $O^{\prime \prime}(\omega)$ の減少率は PC のそれと同じ位である.

\section{$4 \cdot 3$ 修正応力 - 光学則の係数}

修正応力 - 光学則 $(9)$ 式では, 複素ヤング率は相異なる二つの緩 和機構の重なった寄与 $E_{\mathrm{R}}{ }^{*}(\omega)$ と $E_{\mathrm{G}}{ }^{*}(\omega)$ によるあのと仮定す る. 測定值からこれらの成分を求めるには, 係数 $C_{\mathrm{R}}, C_{\mathrm{G}}$ が必要 である.

応力 - 光学係数 $C_{\mathrm{R}}$ は, 低周波数領域で $E^{*}(\omega)$ と $O^{*}(\omega)$ が比例 する領域から求めるべきであるが，Fig. 1 にはそのような領域が 含まれない，今までの様々の高分子の結果から，このような場合 には $E^{\prime}(\omega)$ と $O^{\prime}(\omega)$ が比例する低周波数の領域で $O^{\prime}(\omega) / E^{\prime}$ $(\omega)=C_{\mathrm{R}}$ としてよいことがわかっている( ${ }^{5)}$. これから求める と,

$$
C_{\mathrm{R}}=-8.3 \times 10^{-9} \mathrm{~Pa}^{-1}
$$

一方, ガラス状応力 - 光学係数 $C_{\mathrm{G}}$ は, ガラス状領域で $E^{\prime \prime}(\omega)$ と $O^{\prime \prime}(\omega)$ の比較から求めるべきあのである。しかし上述したよう に式(8)の関係は成り立たず， $O^{\prime \prime}(\omega) / E^{\prime \prime}(\omega)$ は周波数が高くなる につれて減少する。 したがって，一定な $C_{\mathrm{G}}$ を求めるのは不可能 である。これはガラス状領域の副緩和による $E^{\prime \prime}(\omega)$ の挙動の特異 性に起因すると思われる.このような P2VN の副緩和の光学特性 は, 他の高分子のそれとは違っている. 例えば, PS, PMSのガラ 又領域で $E^{\prime \prime}(\omega)$ は (Fig. 1(A) の直線), phenyl 基が主鎖に存在 して副緩和の介入がほとんどないと思われる PC の $E^{\prime \prime}(\omega)$ より高 い值を示し，副緩和が介入していると思われる，けれども，対応 する $O^{\prime \prime}(\omega)$ の変化傾向は $E^{\prime \prime}(\omega)$ と同じで一定な $C_{\mathrm{G}}$ を与える.こ のことから P2VN の副緩和はPS と PMS のそれと異なる挙動を 取っていると思われる.

今まで解析したどの高分子でも $C_{\mathrm{G}}$ の值は, ガラス領域での $O^{\prime \prime}$ $(\omega)$ のピークを示す $\omega$ より一桁高い $\omega$ で計算した $E^{\prime \prime}(\omega) / O^{\prime \prime}$ $(\omega)$ の值と同じである. P $2 \mathrm{VN}$ の $E^{\prime \prime}(\omega)$ と $O^{\prime \prime}(\omega)$ の高周波数での 比較からは $C_{\mathrm{G}}$ は求められないが, ガラス状領域で $O^{\prime \prime}(\omega)$ のピー クを示す $\omega$ より一桁高い $\omega$ での $E^{\prime \prime}(\omega) / O^{\prime \prime}(\omega)$ に等しいと仮定 すると

$$
C_{\mathrm{G}}=1.6 \times 10^{-10} \mathrm{~Pa}^{-1}
$$

である. この周波数は $C_{\mathrm{G}}$ が求め得る最低の周波数であり，副緩 和の効果が比較的小さいと思われる．必ずしも満足とはいえない が，この值を用いて修正応力 - 光学則による解釈を試みる.

\section{$4 \cdot 4$ 修正応力 - 光学則による動的ヤング率の分離}

各温度で測定したデー夕に対して $C_{\mathrm{R}}, C_{\mathrm{G}}$ を使って, 式(9)を連 立方程式と考えて $E_{\mathrm{R}}{ }^{*}(\omega)$ と $E_{\mathrm{G}}{ }^{*}(\omega)$ を求めた。 また分離された 成分のそれぞれに対し, 温度 - 時間換算則を用いて $E_{\mathrm{R}}{ }^{*}(\omega), E_{\mathrm{G}}{ }^{*}$ $(\omega)$ のそれぞれの合成曲線を作成した。基準温度はやはり $160^{\circ} \mathrm{C}$ とした. Fig.4に $E_{\mathrm{R}} *(\omega), E_{\mathrm{G}}{ }^{*}(\omega)$ 成分関数の合成曲線を示す。

図から見られるように，ガラス状成分関数 $E_{\mathrm{G}}{ }^{*}(\omega)$ の周波数依 存性は非常に単純である。 $E_{\mathrm{G}}{ }^{\prime}(\omega)$ は単純増加の, $E_{\mathrm{G}}{ }^{\prime \prime}(\omega)$ は増加 して極大を示してから減少する形を取る。特に， $E^{\prime \prime}(\omega)$ の極大を 示す周波数 $\omega_{\mathrm{MAX}}$ より低周波数領域での $E_{\mathrm{G}}{ }^{*}(\omega)$ の変化形態は, 今まで測定した多種の高分子で観察した挙動と類似な挙動であ る. $\omega_{\mathrm{MAX}}$ より高周波数領域の $E^{\prime}(\omega)$ の高さのみ異なるのを除い

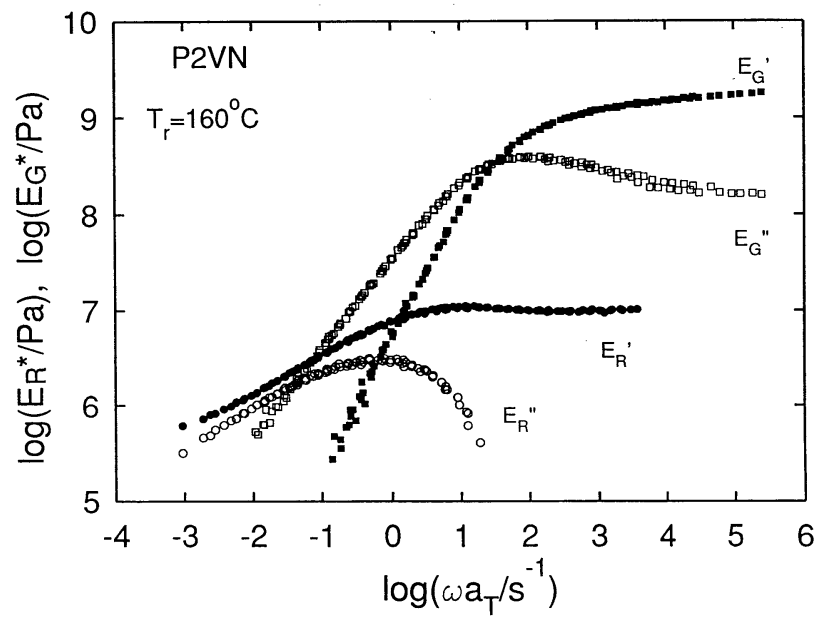

Fig. 4 Master plot of component functions $E_{\mathrm{R}}{ }^{*}(\omega)$ and $E_{\mathrm{G}}{ }^{*}(\omega)$ of $\mathrm{P} 2 \mathrm{VN}$ seperated from $E^{*}(\omega)$ with modified stress-optical rule. The reference temperature is $160^{\circ} \mathrm{C}$

ては, $E_{\mathrm{G}}{ }^{*}(\omega)$ スペクトルは基準温度を適当に選択すれば高分子 の種類に関係なくほとんど類似な緩和挙動を取る ${ }^{13)}$. 一方， $E_{\mathrm{R}}{ }^{*}$ ( $\omega)$ スペクトルは低周波数領域で，匂配 $1 / 2$ に近いべき乗則で近 似的に表すことができる.これは Rouse 模型の挙動と同じであ り，既に報告した多数の高分子であ同様であった．P2 VNであ R 成分を Rouse セグメントの運動による緩和と解釈できることを 示している ${ }^{14)}$.

特に注目すべきことは，ガラス状領域の貯蔵弾性率 $E^{\prime}(\omega)(=$ $\left.E_{\mathrm{R}}{ }^{\prime}(\omega)+E_{\mathrm{G}}{ }^{\prime}(\omega)\right)$ に対する各成分の寄与である. ガラス状領域 の $E^{\prime}(\omega)$ に対してゴム状弾性率の寄与 $E_{\mathrm{R}}{ }^{\prime}(\omega)$ は完全にはなくな らないことである。これはガラス状領域でゴム状弾性率の寄与が 消えると仮定する Read ${ }^{15), 16)}$ と Priss ${ }^{17)}$ の考察とは異なる結果で ある. 物性と $E_{\mathrm{R}}{ }^{\prime}(\omega), E_{\mathrm{G}}{ }^{\prime}(\omega)$ 成分関数の特性との明確な関連性 は把握されてないが，他の力学的特性つまり延性や疲労破壊特性 などとの関連性があるかも知れない，さらに周波数が低くなるに 従って，成分 $E_{\mathrm{G}}{ }^{\prime}(\omega)$ の寄与は傾き 2 で急激に減少してゆき，同 時にガラス転移領域から成分 $E_{\mathrm{R}}{ }^{\prime}(\omega)$ の寄与が急激に大きくな る. ゴム状領域に入っては $E_{\mathrm{G}}{ }^{\prime}(\omega)$ の寄与は完全になくなり，こ れは現象論的な考察とも一致する.

損失弾性率 $E^{\prime \prime}(\omega)$ への各成分の寄与は, 高周波数領域では成分 $E_{\mathrm{R}}{ }^{\prime \prime}(\omega)$ の寄与は無視できるほど小さく, ガラス成分 $E_{\mathrm{G}}{ }^{\prime \prime}(\omega)$ の寄 与が主になっている．周波数が低くなりガラス転移領域へ入って あ主な寄与はガラス成分であり，ゴム平坦域で始めてガラス状成 分の寄与は傾き 1 で減少してなくなっていくのがわかる。

\section{$4 \cdot 5$ 他の高分子と複屈折の特性係数の比較}

$\mathrm{P} 2 \mathrm{VN}$ の複屈折および $E_{\mathrm{R}}{ }^{*}(\omega), E_{\mathrm{G}}{ }^{*}(\omega)$ の特性を, 分子構造の 異なる他の高分子のと比較してみるために, Table I にPS, PMS, PC の特性值を記す。

まず $C_{\mathrm{R}}$ を比べると，高分子の分子鎖構造によって符号と大き さは著しく異なる. P2VN, PMS, PS は負の值を, PC は正の值を 示す. ゴム状領域のひずみ - 光学係数の符号は，大きい光学異方 性を示す naphthyl 環や phenyl 環が側鎖にあるか主鎖にあるか で決定される，P2VN，PSのゴム状領域では，延伸変形により側 
Table I. Charateristic values for P2VM, PS, PMS, and PC.

\begin{tabular}{|c|c|c|c|c|c|c|c|c|}
\hline Polymers & $\begin{array}{l}E_{\mathrm{N}}{ }^{0 \mathrm{a}} \\
(\mathrm{MPa}\end{array}$ & $\begin{array}{l}E_{\mathrm{R} \infty}^{\prime} \\
(\mathrm{MPa}\end{array}$ & $\begin{array}{l}\left.E_{\mathrm{G} \infty}^{\prime} \mathrm{c}\right) \\
(\mathrm{MPa})\end{array}$ & $\begin{array}{l}E_{\mathrm{R}, \max }^{\prime \prime} \\
(\mathrm{MPa})\end{array}$ & $\gamma^{d)}$ & $\begin{array}{c}C_{\mathrm{R}} \\
(\mathrm{Br})\end{array}$ & $\begin{array}{c}C_{\mathrm{G}} \\
(\mathrm{Br})\end{array}$ & $\begin{array}{c}T_{\mathrm{r}} \\
\left({ }^{\circ} \mathrm{C}\right)\end{array}$ \\
\hline P2VN & - & 10 & 1700 & 3.0 & 130.6 & 8300 & 160 & 160 \\
\hline PMS & - & 16 & 2300 & 4.5 & 22 & -3400 & 20 & 176 \\
\hline PS & 0.6 & 12 & 2500 & 3.3 & 44 & -5000 & 32 & 116 \\
\hline BPA-PC & 8 & 26 & 1500 & 3.1 & 11 & 5000 & 35 & 160 \\
\hline
\end{tabular}

a) Rubbery plateau modulus.

b) Limiting storage modulus of rubbery component function in higher frequencies.

c) Limiting loss modulus of glassy component in higher frequencies.

d) Ratio of frequencies where the $E_{\mathrm{G}}$ " and $E_{\mathrm{R}}{ }^{\prime \prime}$ show maximum.

${ }^{\text {e) }} \mathrm{Br}$ represents Brewsters which is equal to $10^{-12} \mathrm{~Pa}^{-1}$.

鎖の配向度が大きく変わり，延伸方向に垂直な phenyl 基の数が 増加するため, $n_{11}$ より $n_{22}$ の值が大きくなり， $C_{\mathrm{R}}$ は全体で負の 符号を示すことが理解できる. Naphthyl 基を持っ P $2 \mathrm{VN}$ は phenyl 基を持つ PS より絶対值で 1.6 倍大きい.

一方，多種の高分子の測定から定められたガラス状応力 - 光学 係数 $C_{\mathrm{G}}$ は, phenyl 基などの配置（主鎖中か側鎖か）にさほど影 響を受けないように見られる．特に, phenyl 基を含む高分子の $C_{\mathrm{G}}$ はほとんど一定であり約 $30 \mathrm{Br}$ 程度を示す. ポリオレフィン, ポリイソプレンなど, phenyl 基ほよ゙の大きな基を含まない高分 子では $C_{\mathrm{G}}$ は負であり, 值は小さい. $\mathrm{P} 2 \mathrm{VN}$ の $C_{\mathrm{G}}$ は, 決定に若干 問題を含んでいるが, $160 \mathrm{Br}$ であり phenyl 基を含む高分子より 約 5 倍ほど大きい.

$C_{\mathrm{G}}$ については次のような考察をしてみることができる．高分 子鎖の配向による複屈折，つまり $\mathrm{R}$ 成分を理論的に取り扱う場 合, セグメントは軸対称性のある光学異方性棈円体であると仮定 される.この時の複屈折は

$$
\Delta n=\left\{\alpha_{1}-\left(\alpha_{2}+\alpha_{3}\right) / 2\right\} F_{200}
$$

と表される.ここで 1 は主鎖に沿った方向を，2，3 はそれと垂直 な方向を示し， $\alpha_{1}, \alpha_{2}, \alpha_{3}$ はセグメントのそれぞれ方向の分極率 である. $F_{200}$ は配向関数で,

$$
F_{200}=\left(3<\cos ^{2} \theta>-1\right) / 2
$$

であり, $\theta$ は軸 1 と伸長方向がなす角度である.

セグメントの光学異方性楕円体が軸対称でなければ光学異方性 棈円体が主鎖の軸回りに回転して, 変形方向に配向する可能性が ある.この時の複屈折は

$$
\Delta n=\left\{\alpha_{1}-\left(\alpha_{2}+\alpha_{3}\right) / 2\right\} F_{200}+\left(\alpha_{2}-\alpha_{3}\right) F_{202}
$$

になる. $F_{202}$ は軸 1 回りの回転による配向を表す関数で,

$$
F_{202}=\left\langle\sin ^{2} \theta \cos 2 \eta\right\rangle
$$

であり, $\eta$ は軸 1 回りの回転角度である. 主鎖の軸回りの回転が 自由になれば, $F_{202}$ は 0 となり, 複屈折は主鎖方向のみで決まり 式(13)に帰着する.これはゴム状領域の挙動として一般的に認めら れている. P2VN のように 2 方向が崇高い構造を取る場合, $\left(\alpha_{2}-\right.$ $\left.\alpha_{3}\right)>0$ となり, 主鎖軸回りの回転が緩和するまでは $\left(\alpha_{2}-\alpha_{3}\right) F_{202}$ に対応する正の複屈折が発生しうる.これが高分子の $C_{\mathrm{G}}$ を決め る主な因子と思われる. 大きな naphthyl 基をむつ P2VNの $\left(\alpha_{2}\right.$ $\left.-\alpha_{3}\right)$ は, phenyl 基のそれより著しく大きいであろう。それに
よって, ガラス状領域でのひずみ - 光学係数は異なった挙動を取 り, $\mathrm{P} 2 \mathrm{VN}$ と phenyl 基を含む他の高分子の $C_{\mathrm{G}}$ の值に大きい差 が生じたと思われる.

Table I の $\gamma$ は, 分離された二つの $E_{\mathrm{R}}{ }^{\prime \prime}(\omega), E_{\mathrm{G}}{ }^{\prime \prime}(\omega)$ のスペク トルでピークを表す周波数の比である.つまり, 相異なる二つの 特性の緩和挙動がごのくらい離れて存在しているかの尺度であ り, 各高分子の他の物性例えば勒性 (toughness) 之関連して考察 できるであろう。ここでは議論しないがデータとして記してお $<$.

\section{$4 \cdot 6$ 移動因子 $a_{\mathrm{T}}$ の温度依存性}

$E^{*}(\omega), O^{*}(\omega), E_{\mathrm{R}}{ }^{*}(\omega), E_{\mathrm{G}}{ }^{*}(\omega)$ の合成曲線を作成する際, 求めた移動因子の温度依存性を Fig. 5 に表す. $E^{*}(\omega)$ と $O^{*}(\omega)$ の換算因子の温度依存性を見ると, 低温領域を除いては二つの特 性值の温度依存性はほとんど同じである. 低温領域（高周波数領 域）の一部で二つの特性值の温度依存性が異なり, ひずみ - 光学 係数より弾性率の活性化エネルギーが若干大きいことがわかる. この傾向は既に報告した $\mathrm{PS}^{5)}, \mathrm{PC}^{7), 8)}$ の傾向とあ同じである.こ のことから力学的特性值と複屈折特性值の緩和挙動は異なり, 同 じ変形に対して複屈折緩和は力学的緩和より速い応答を示すのが わかる.

二つの特性関数 $E_{\mathrm{G}}{ }^{*}(\omega)$ と $E_{\mathrm{R}} *(\omega)$ の温度依存性む, やはり全 体としてはほとんど同じである. 低温領域の端で $E_{\mathrm{G}}{ }^{*}(\omega)$ の温度 依存性は $E_{\mathrm{R}}{ }^{*}(\omega)$ のそれより若干大きい. PS と $\mathrm{PC}$ の場合, ガラ 又転移領域 $E_{\mathrm{G}}{ }^{*}(\omega)$ の温度依存性は $E_{\mathrm{R}}{ }^{*}(\omega)$ のそれより非常に 大きい結果を見せ ${ }^{5) ~ 8), ~}$ 相異なる緩和機構の存在を確認すること ができた. したがって二つの異なる機構の重なったこの領域で, 弾性率に対して時間 - 温度換算則を適用するのが非合理的であっ た。しかし，P2VN の場合二つの機構の温度依存性がほぼ類似で あり，ガラス転移領域近傍で時間 - 温度換算則を取り扱うのはさ

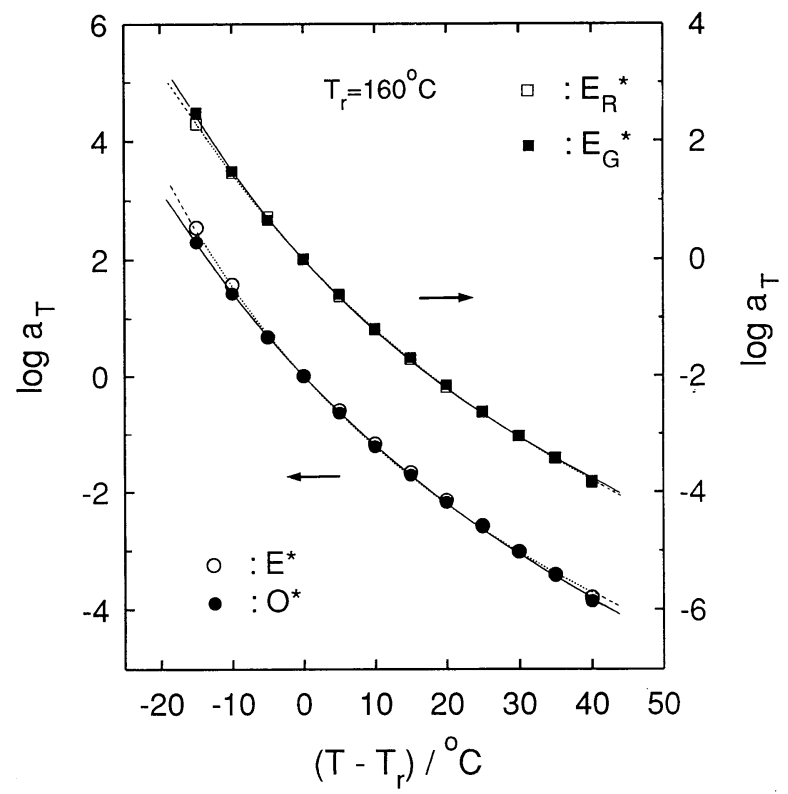

Fig. 5 Temperature dependence of the time-temperature shift factors of $E^{*}(\omega), O^{*}(\omega), E_{\mathrm{R}}{ }^{*}(\omega)$ and $E_{\mathrm{G}} *(\omega)$. Reference temperatures are the same as $160^{\circ} \mathrm{C}$. 
Table II. Parameters of WLF fitting to the shift factors obtaind for the respective relaxation spectra. Reference temperatures are the same as $160^{\circ} \mathrm{C}$.

\begin{tabular}{ccrc}
\hline Spectra & $C_{1}$ & $C_{2} / \mathrm{K}$ & $N_{\text {orm }}$ \\
\hline$E^{*}$ & 11.6 & 85.0 & 0.18 \\
$O^{*}$ & 14.0 & 107.5 & 0.09 \\
$E_{\mathrm{R}}{ }^{*}$ & 13.7 & 104.6 & 0.06 \\
$E_{\mathrm{G}}{ }^{*}$ & 12.4 & 92.0 & 0.16 \\
\hline
\end{tabular}

ほど無理ではない.

この領域での移動因子の温度依存性はWLF 式により表すこと ができる2).

$$
\log a_{\mathrm{T}}=c_{1}\left(T-T_{\mathrm{r}}\right) / c_{2}+\left(T-T_{\mathrm{r}}\right)
$$

Table II は上の WLF 式による解釈結果を示す. Fig. 5 の実線 および点線は各々対応する特性值の WLF 式によるフィッテング 結果である. 物質の基礎データとして附記しておく.

\section{参考 文 献}

1) Alegria A, Macho E, Colmenero J, Macromolecules, 24, 5196 (1991).

2) Ferry JD, "Viscoelastic Properties of Polymers", 3rd Ed, John Wiley and Sons, New York, 1980.

3) Janeschitz-Kriegl H, "Polymer Melt Rheology and Flow Birefringence", Springer-Verlag, Berlin, 1983.
4) Wales JLS, "The Application of Flow Birefringence to Rheological Studies of Polymer Melts", Delft Univ. Press, Delft, Netherlands, 1976.

5 ) Inoue $\mathrm{T}$, Okamoto $\mathrm{H}$, Osaki K, Macromolecules, 24, 5670 (1991).

6) Inoue $\mathrm{T}$, Hwang EJ, Osaki K, J Rheol, 36, 1737 (1992).

7) Hwang EJ, Inoue T, Osaki K, Polymer, 34, 1661 (1993).

8) Inoue $\mathrm{T}$, Hwang EJ, Osaki K, Bull. Inst Chem Res, Kyoto Univ, 70, 162 (1992).

9) Hwang EJ, Inoue T, Osaki K, Polymer (Korea), 17, 249 (1993).

10) Inoue $T$, Okamoto $H$, Hayashihara $H$, Osaki $K$, Nihon Reoroji Gakkaishi, 19, 93 (1991).

11) Plazek DJ, J Phys Chem, 69, 3480 (1965).

12) Treloar LRG, "The Physics of Rubber Elasticity", 3rd ed, Clarendon Press, Oxford, 1975.

13) Robert GE, White EFT, "The Physics of Glassy Polymers", John Wiley and Sons, New York, 1973.

14) Doi M, Edwards SF, "The Theory of Polymer Dynamics", Clarendon Press: Oxford, 1986.

15) Read BE, Polymer, 3, 143 (1962).

16) Read BE, Polym Eng Sci, 23, 835 (1983).

17) Priss LS, Vishnyakovm II, Pavlova IP, Int J Polym Mat, 8, 85 (1980). 